\title{
Product Design Management and Global Competition
}

\author{
Silvio M. Brondoni*
}

\begin{abstract}
For global corporations, achieving a differential advantage in terms of product design means designing an offer based on the best interpretation of specific distinctive characteristics, and to this end, information must be collected in continuum from the market, about customers and competitors.

Corporate imitation and innovation processes have come to represent a primary condition to stand up to global competition on the markets, which takes the shape of identifying by the design management products with 'new' features to propose to customers that change in time and space.

A global firm's success is conditioned by its ability to manage the system of corporate intangible assets (corporate culture, corporate identity and information system), and product intangible assets (product design, brand equity and prelaftersales services). In global firms, design is a strategic element linking the product intangibles and the firm's intangible assets.
\end{abstract}

Keywords: Product Design; Design Management; Global Corporations; Imitation; Innovation; Global Competition; Intangible Assets

\section{Global Product Design, Innovation and Imitation}

Global markets radically changed temporal and spatial competitive landscapes and created new frontiers for competition and relationships. Globalisation overcomes indeed any static or delimited notion of competitive space (market-space management). As a result, specific geographical contexts are required to exhibit unique, partial, competitive advantages (regarding production, marketing, $\mathrm{R} \& \mathrm{D}$, etc.) (Lambin 2000).

Globalisation forces a company to have at its disposal a wide range of spaces and objects in order to make comparisons. It also simultaneously presupposes an information system consistent with very short-term decision-making: a system based on electronic data flow and open communication processes (as opposed to the traditional one-way processes from sender to passive receiver) (Brondoni 2003).

In particular, a global company success is conditioned by its ability to manage the system of corporate intangible assets (corporate culture, corporate identity and information system), and product intangible assets (product design, brand,

\footnotetext{
* Full Professor of Management, University of Milan-Bicocca (silvio.brondoni@ unimib.it)
} 
pre/after-sales services) from a competitive or market-driven point of view (Brondoni 2010).

Imitation and innovation processes have become a primary condition to stand up to global competition on the markets, and the design of products with 'new' tangible and intangible components is closely linked to market research carried out to identify particular consumer needs (Brondoni 2012a).

Product design defines the functions that qualify a product or service, in order to identify and organise the distinctive specifications of the firm offer, and to develop goods and services based on the analysis of demand needs (customer satisfaction).

In global over-supplied markets, product design is a strategic tool that corporations can use to gain a durable and sustainable competitive advantage. Design-driven firms focus product design on competitive processes for improving products, communications and corporate identity.

\section{Competitive Product Design Management: from Planned Obsolescence to Zero Defects}

Design management is a leadership activity, focused on managing the creation of a concept. The concept may be an object (motor car, building, etc.), an event (conference, wedding, etc.), or a relationship (such as that between firms and employees). Interest in design has grown as a result of global competition and the growing importance of non-price factors in firm competitiveness.

To maintain profit margins, firms need to focus on the improvement of the design process, especially to cope with competition. From a creative perspective, all designs are unique and therefore they cannot be planned or managed. This view is outdated and no longer valid. In a managerial perspective, design is instead a process, which can be largely repeated from one project to the next and therefore can be defined, measured and improved.

In today's digital age with an ever growing consumers interest on more sophisticated products and services, increasing product complexity significantly impacts on design management practice. The need to integrate different technologies, and thus project management, has emerged as an important discipline for achieving these objectives. The functionality of new production systems serving the changing markets is crucial in responding to shorter product life cycles and market dynamics (Christiaans, Almendra 2010).

In the last fifteen years, design-oriented companies have transformed their design concept from a differentiation tool to a transformation value. The trend of this strategy emerges as companies consider design processes not only as project management tools but also as organizational capabilities that provide superior competitive strength and customer satisfaction.

In the last ten years all the Korean chaebols (Hyundai, Kia, Amore Pacific, KTF, Daewoo Electronics, LG Electronics, and Samsung Electronics) have become particularly sensitive to new design trends. They have made the transition from design as a marketing tool to design as a corporate core competence. Indeed, they believe that design-driven management is a strategic corporate capability for the export markets and the Korean market too (Borja De Mozota, Young Kim 2009) 
The design management can be oriented to different competitive edges, that specifically concern products based on planned obsolescence, total quality, or even a competitive philosophy of zero defects.

\subsection{Competitive Design Management Focused on Planned Obsolescence}

With planned obsolescence, a product is deliberately designed to have a specific life span. This is usually a shortened life span. The product is designed to last long enough to develop a customer's lasting need (Bulow 1986).

For a washing machine, for instance, planned obsolescence means that the washing machine is designed to last about two years, before it breaks down outside the guarantee time. Most of the components have been manufactured from quality materials with the exception of some vital parts. Two years after purchase, the washing machine will only need minor inexpensive repairs. However, between 4 to 5 years the vitals parts begin to wear out and a replacement machine is required.

Planned obsolescence is sometimes designed into a product, in order to encourage the customer to buy the next upgrade.

$\square$ Mobile phones are often designed with only current technology in mind, despite the manufacturer's knowledge of future technological developments.

Obsolescence can affect all systems, especially military systems which are designed for a long product life.

$\square$ Military systems typically outlive most of their internal components, giving rise to parts obsolescence. In the past 10 years, parts obsolescence is accelerated by the wave of progress in electronics and material innovations. To maximise the value of a military system, obsolescence should be managed throughout the system's life cycle (Lua Yali et al. 2012).

Product designed on the philosophy of 'built in obsolescence' leaves usually customer confidence in the product and manufacturer intact. In this sense, planned obsolescence is sometimes deliberately and openly built into products for safety reasons (Schmalensee 1979, 1970).

$\square$ Sell by dates and use by dates on foods, are a guide to both the retailer and customer, highlighting when a food product is safe to eat and at its best. Further examples are disposable cutlery and soft drinks bottles, which are manufactured cheaply and designed to be used onceltwice.

The role of the design in the management of obsolescence can be very important. As technology moves towards faster, better, more efficient devices and products, 
designers are faced with the difficult choice of whether to use a component which is readily available and has been on the market, but runs the risk of becoming obsolete more quickly (Swan 1972).

Product design management focused on planned obsolescence is strictly linked to many types of counterfeits too (Brondoni 2012a). Counterfeit includes used components represented as new, parts from an unapproved manufacturer represented as though they were manufactured by the approved source. Counterfeit product may often appear as genuine but it is later revealed it was not built to the same quality standards or tested as a genuine item, or not manufactured by the original components or materials.

As components become unavailable through original equipment manufacturers, and their authorised distributors, the pressure on those supporting products with a long in-service life to source devices and equipment from unofficial sources inevitably creates a demand, which can be filled by the counterfeit component industry.

\subsection{Competitive Design Management Focused on Total Quality}

Design management focused on total quality refers to an engineering design method used to enhance quality and productivity in organisations. Quality needs to be built into every level of a company, and become part of the organisation's own culture. Design management focused on total quality is thus a comprehensive systems approach that works horizontally across an organisation, involving all departments and employees and extending backward and forward to include both suppliers and clients/customers. By improving quality, companies will decrease expenses as well as increase productivity.

$\square$ Although TQM techniques were adopted prior to World War II by a number of organizations, the creation of the total quality management philosophy is generally attributed to W. Edwards Deming. In the late 1920s, Deming devised a statistically controlled management process that provided managers with a means of determining when to intervene in an industrial process. During World War II, Government managers found that Deming' techniques could easily be taught to engineers and workers, and then quickly implemented in overburdened war production plants (Deming 1982).

In 1947, the U.S. State Department sent Deming to Japan as part of a national effort to revitalize the war-devastated Japanese economy. In Japan Deming found an enthusiastic reception for his management ideas (Crawford 1998; Dillon 1990; Hayes 1981).

Design management focused on total quality allowed the Japanese industries to become a dominant force in the international markets by the 1970s (Takeuchi 1981).

Japanese corporations like Toyota, Fuji, and Sony obtained rapidly a great and growing success. Their quality was far superior to that of their western competitors, and their costs were lower. The demand for Japanese products soared - and by the 1980s, many of these companies dominated the global markets. By contrast, 
American and European companies realised just in the 2000s that they could no longer ignore the quality revolution (Brondoni 2013). In fact, total quality in the United States was just in direct and late response to a quality revolution in Japan following World War II, as major Japanese manufacturers converted from producing military goods for internal use to producing civilian goods for trade (Hiam 1992).

$\square$ The Toyota Corporate Philosophy of Total Quality Management. Toyota launched the Creative Idea Suggestion System in 1951 and introduced in June 1961the Total Quality Circles, making substantial contributions to the company's development. Based on the corporate philosophy of 'customer first' and 'quality first' since its founding, Toyota Motor Co., Ltd. has conducted Total Quality Management (TQM) based on the unchanging principles of 'customer first', kaizen (continuous improvement), and 'total participation'. As a result, the basic concepts of TQM and problem solving as well as kaizen (continuous improvement) through creative innovation spread throughout the company and took root, contributing to higher product quality and work quality at all levels and ranks and improving the vitality of individuals and organizations (Imai1986).

While Japan's industrial corporations embarked on a total quality design approach during the middle $1900 \mathrm{~s}$, most American firms continued to produce mass quantities of goods using traditional industrial design techniques (Hiam 1992; Hunt 1992).

The traditional US design approach is "to compare actual costs with flexible budgets based on engineer driven standard costs. However, standard costs are based on the static optimization concept where standards are set based on the current plant and resource constraints. The emphasis is on achieving the internal standard rather than continuously reducing costs to achieve the external goal" (Martin et al. 1992).

By contrast, Japanese firms focused on total quality design "compare actual costs to market driven target costs. Target costs are established somewhere between standard costs and allowable costs which are determined by subtracting a target profit margin from the target price. The target price is the price that would provide the company with a competitive edge in the market. This approach is dynamic since the target costs are continuously reduced, both during and after the design stage to promote continuous improvement" (Martin et al. 1992).

In a design approach focused on total quality, the characteristics to succeed within an organisation are participative management; continuous process improvement; the utilisation of teams; prevention versus inspection (inspections are costly, unreliable and they do not improve quality: but they can just find a lack of quality); feedbacks and feedforwards on quality; and suppliers considered as partners in quality (encouraging them to spend time and money improving their own quality) (Jablonski 1992).

The costs of implementing an approach of design management focused on total quality are less important than the direct and indirect costs linked to problems of quality non-conformance. The costs that firms may avoid can be identified in the 
costs of prevention (quality planning; product specifications; training), appraisal (vendor approval; quality audits; inspections and verifications of incoming materials), internal failure (waste and scrap; failure analysis; removal of errors or defective materials; reworks) and external failure costs (complaints; warranty claims; returns; transportation; repairs).

Japan's strategies represented the new total quality approach focused on a vision of international design product engineering. Rather than relying purely on product inspections, Japanese manufacturers focused on improving all organizational processes through the people who used them. As a result, Japan was able to produce higher-quality exports at lower prices, benefiting consumers throughout the world. Therefore, the business world developed a new relation between design, quality, production and price.

\subsection{Competitive Design Management Focused on Zero Defects}

With a design engineering philosophy focused on zero defects product, a firm can increase profits both by eliminating the cost of failure and increasing revenues through a better customer satisfaction.

Zero Defects is a management program tool aimed at the reduction of defects through prevention in industrial production. Every defect represents a cost, which is often hidden (Halpin 1966). These costs include inspection time, rework, wasted material and labor, lost revenue and the cost of customer dissatisfaction. When properly identified and accounted for, the magnitude of these costs can be made apparent (Crosby 1979).

The culture of design management focused on zero defects reinforces the basic tenets of lean production for waste minimization and continuous improvement. This concept was originally developed in Japan in the mid-1970s by the Toyota Motor Corporation and it emphasised the avoidance of waste of materials, space, and labor. Operations were constantly being improved and fine-tuned so as to further eliminate waste and thereby increase productivity and yield.

$\square$ The then-chairman of General Electric, Jack Welch, was quoted in an article by Theodore Levitt as asserting that the Japanese, with few natural resources, an alien culture, and a complex language, had cracked the code of Western markets. They discovered what, to Welch, was the one great thing every market has in common-an overwhelming desire for dependable, world-standard performance at aggressively low prices. The Japanese delivered such irresistible value everywhere, attracting people with products that market research would probably not have regarded as marketable (Levitt 1983).

In practice, lean manufacturing (a process for measuring and reducing inventory and streamlining production) and just-in-time production (a set of principles and practices based on the philosophy that firms should hold little or no inventory beyond that required for immediate production or distribution) both express a management system aimed at reducing waste, maximizing cost efficiency, and securing a competitive advantage. Thus, a number of additional conditions are considered necessary for the successful implementation of lean production/JIT 
(small lot sizes, short setup, efficient and effective quality controls), and first of all, designing the whole production process to minimise backups and maximize the efficiency.

In the actual phase of global competition (network globalisation 2010-2020) (Brondoni 2014), the major Japanese corporations are aiming at changing the rule of the competitive game by adding extra value to their products and re-focusing corporate efforts on customer service. From the 1980s, competition among Japanese firms was centred on reaching a zero defect level in product quality; today the emphasis is on achieving zero defects also in customer service, beginning from the concept of the product, i.e. from the industrial design engineering.

The Japanese method for continuous improvement is known as 'kaizen'. This method delivers product improvements very differently from the processinnovation. While innovation is focused on science and technology and it is characterised by costly major events (Feitzinger, Lee 1997), 'kaizen' is focused on design and production, for inexpensive and almost imperceptible continuous improvements.

$\square$ An example of superiority of kaizen-design against innovation in the race for competitive advantage was the reduction of dip soldering failures at Yokogowa Hewlett-Packard (YHP). For a little more than two years, the continuous improvement process on average produced a $50 \%$ reduction in the failure rate every 3.6 months. Defects were reduced by a factor of over 250. What was the incremental cost to YHP in going from a defect rate of 3 ppm to 2 ppm? What was the incremental return? A detailed cost analysis could probably capture all of the costs and benefits, but the results can be guessed. The incremental costs are essentially zero. After 20 months of continuous improvement (at an improvement rate of 50\% each 5.1 months) and a tenfold reduction in scrap, the problem was declared solved and all efforts toward further improvement abandoned (Sasaoka 1984).

The use of lean/JIT improves the firm's internal quality as well as the quality of suppliers.In a theoretical model for optimum quality costs it is possible to define three quality zones relative to the point of minimum total quality costs. The so called 'zone of improvement projects' lies below the optimum quality level, while the 'zone of perfectionism' lies above it. Between them, and in the area of the minimum, lies the 'zone of indifference' (Juran 1979). Thus optimum quality costs depend on incremental, not total, elementary costs. At the optimum, nothing in general can be said about the relative levels of prevention and failure costs (Schneiderman 1986). The optimum (or more correctly, the minimum) quality cost could lie at zero defects if the incremental cost of approaching zero defects is less than the incremental return from the resulting improvement. The incremental cost is infinite, whereas the incremental return is not (Juran 1979).

Design management focused on zero defects endorses continuous product improvements. This is the never-ending effort to totally eliminate all forms of error, including reworks, over-design, unproductive time, inventory, idle facilities, and many non-tangible factors (Schneiderman 1986). 


\section{Design Management in Global Firms}

In global markets, design management is becoming a vital necessity, as it enables an organisation to successfully deploy design for innovation purposes, stay in sync with the market, satisfy consumer needs, and realize benefits in competitive market-spaces (Liedtka, Ogilvie 2011).

From a general point of view, design management focuses on design as 'the purposive application of creativity to all the activities necessary to bring ideas into use either as product (service) or process innovations' (Bruce, Bessant 2002).

More specifically, industrial firms can use design as a marketing tool for product differentiation (Borja de Mozota 2006; Bruce, Jevnaker 1998). In this operational sense, design creates value for the firm's primary activities, but it remains only an external, market-based advantage derived from the firm design-based differentiation policy, as noted also by EU Commission.

$\square$ The role of design is to strengthen the communication between the different parts of the innovation process, for example between $R \& D$ and production, $R \& D$ and marketing, to turn ideas and technological inventions into products and services, and make innovative products commercially acceptable, user-friendly and appealing. In this sense, design is a tool for innovation in new or emerging markets where userfriendly and appealing design is a must to create or enter the market, or to bring only marginal improvements to the end-user (EU Commission 2009).

In global corporations design management is a competence that comes under the umbrella of innovation management, in recognition of the fact that firm innovation capability matches threats with new market opportunities. Indeed, global firms have reoriented their competitive strategies focused on innovation. In open markets where competition is strong, innovation has lost its role of 'ideological hierarchy' over imitation; and at present both have the common goal of maximising company profitability, with the constraint of optimising performance results in the very short term.

When design management is an explicit part of management processes, it has greater impact on business performance and helps secure a market position for the long term. Design management has a formal set up, it is part of a firm's policymaking process, and it interfaces with other managerial functions.

In a more complex vision, design becomes a management factor of functional coordination and integration. In this case, design becomes a competitive advantage coming from a combination of organizational processes and resources (that is, design as a process). The differentiation approach is instead adopted by firms that use design on a limited basis in ad-hoc style changes, product line extensions, or product improvement projects. In these companies, design is largely neglected as a significant tool for innovation processes. Design is primarily used as a commercial tool, with a view to adding value to the existing product offer (through product appearance, styling, packaging, marketing communication, or visual identity) (Kootsra 2009). 
Since 2000s global markets have developed trends of mass customisation which have imposed something more than a simple 'fine tuning' of existing operations. Globalisation moved towards an active role of design with user's involvement in projects and in production, which may redesign the complete operations structure within the firm's plants.

Although users have always been seen as an important element in the design process, global competition highlights the importance of a design-active paradigm (von Hippel 2005, 1998).

Global competition stated the critical role of 'lead users' in shaping design with new technologies in visualisation, simulation, prototyping and IT, and the active relation between design and customers (Bohemia, Harman 2008).

Instead of taking a piecemeal approach, companies must rethink and integrate the designs of their products, the processes used to make and deliver those products, and the configuration of the entire supply network. By adopting such a comprehensive approach, companies can operate at maximum efficiency and quickly meet customers' orders, with a minimum amount of inventory (Feitzinger, Lee 1997).

Anticipative design management is an incremental continuous iterative process and as the project moves on, it provides feedback and feed-forward points for new information (Doloi 2007).

Anticipative design defines competitive landscapes with specific dimensions for the firm's entire value-chain system, i.e. the network of activities connected by linkages into which design has to penetrate (Rieple, Haberberg, Gander 2005). Obviously a careful management of linkages can offer valuable competitive advantages throughout the value system, as when the design helps by creating interdependencies among a firm and its suppliers and distributors (Borja De Mozota 1998).

Companies with an approach of design management are looking to define themselves as a market leader through design focused on innovation or on imitation, because competitive global networking emphasises the relation between innovation and imitation. The management of global innovation and imitation is driven by competition, through continuous increases in technological advances and accelerating life cycles of customer preferences (Brondoni 2012b).

Firms highly design-driven have innovation and imitation policies at their core (von Stamm 2004). In these firms, the design management process is also considerably involved in the integration of company operations. So products are designed not only to fight competitors and to gain customers, but also to improve product quality, zero defects production and corporate identity. Sony's pioneering designs in transistor radios and later in the Walkman and in the Trinitron TV colour, finds its latest expression in the slim-line VAIO design for lightweight laptops.

In global over-supplied markets, many corporations have turned design management into the key to project success in fast changing markets.

In competitive market-places, design becomes a firm core competence, a strategic intangible asset that adds value through anticipation of changes in the firm competitive environment. 


\section{Bibliography}

Bohemia Erik, Harman Kerry (2008) Globalization and Product Design Education: The Global Studio, Design Management Journal, December, n. 3, 2,.pp. 53-68.

http://dx.doi.org/10.1111/j.19487177.2008.tb00014.x

Borja De Mozota Brigitte, Young Kim Bo (2009) Managing Design as a Core Competency: Lessons from Korea, Design Management Review, n. 20, 2, pp. 66-76.

http://dx.doi.org/10.1111/j.1948-7169.2009.00009.x

Borja de Mozota Brigitte (2006) The Four Powers of Design. A Value Model in Design Management, Design Management Review, n. 17, 2, pp. 44-53.

http://dx.doi.org/10.1111/j.1948-7169.2006.tb00038.x

Borja De Mozota Brigitte (1998) Structuring Strategic Design Management: Michael Porter's Value Chain, Design Management Journal, 9 (2), Spring, pp. 26-31.

http://dx.doi.org/10.1111/j.1948-7169.1998.tb00201.x

Brondoni Silvio M. (2014) Global Capitalism and Sustainable Growth. From Global Products to Network Globalisation, Symphonya. Emerging Issues in Management (symphonya.unimib.it), n. 1, pp. $10-31$.

http://dx.doi.org/10.4468/2014.1.02brondoni

Brondoni Silvio M. (2013) Innovation and Imitation for Global Competitive Strategies. The Corporation Development Models of US, Japan, Korea, and Taiwan, Symphonya. Emerging Issues in Management (symphonya.unimib.it), n. 1, pp. 12 - 27.

http://dx.doi.org/10.4468/2013.1.02brondoni

Brondoni Silvio M. (2012a) Innovation and Imitation: Corporate Strategies for Global Competition, Symphonya. Emerging Issues in Management (symphonya.unimib.it)), n. 1, pp. 10-24.

http://dx.doi.org/10.4468/2012.1.02brondoni

Brondoni Silvio M. (2012b) Managerial Economics and Global Corporations, Giappichelli, Turin.

Brondoni Silvio M. (2011) Global Networks, Knowledge Management and World Cities, Symphonya. Emerging Issues in Management (symphonya.unimib.it), n. 1, pp. 7-18.

http://dx.doi.org/10.4468/2011.1.02brondoni

Brondoni Silvio M. (2010) Intangibles, Global Networks \& Corporate Social Responsibility, Symphonya. Emerging Issues in Management (symphonya.unimib.it), n. 2, pp. 6-24.

http://dx.doi.org/10.4468/2010.2.02brondoni

Brondoni Silvio M. (2008) Market-Driven Management, Competitive Space and Global Networks, Symphonya. Emerging Issues in Management (symphonya.unimib.it), n. 1, pp. 14-27.

http://dx.doi.org/10.4468/2008.1.02brondoni

Bruce Margaret, Bessant John (2002) Design in Business: Strategic Innovation Through Design, Pearson Education, London.

Bruce Margaret, Jevnaker Birgit H. (1998) Management of Design Alliances: Sustaining Competitive Advantage, Wiley, Chichester.

Bulow Jeremy (1986) An Economic Theory of Planned Obsolescence, The Quarterly Journal of Economics, n. 101, 4, pp. 729-749.

http://dx.doi.org/10.2307/1884176

Christiaans Henri, Almendra Rita Assoreira (2010) Accessing Decision-Making in Software Design, Design Studies, November, n. 31, 6, pp. 641-662.

http://dx.doi.org/10.1016/j.destud.2010.09.005

Crawford Roy J. (1998) Reinterpreting the Japanese Economic Miracle, Harvard Business Review, January-February, pp. 179-184.

Crosby Philip B. (1984) Quality Without Tears: The Art of Hassle-Free Management, McGraw-Hill, New York. 
Crosby Philip B. (1979) Quality Is Free: The Art of Making Quality Certain, McGraw-Hill, New York.

Deming W. Edwards (1982) Out of the Crisis, MIT Center for Advanced Engineering Study, Cambridge.

Dillon Lawrence S. (1990) Can Japanese Methods be Applied in the Western Workplace?, Quality Progress, October, pp. 27-30.

Doloi Hemanta Kumar (2007) Developing an Integrated Management System for Optimising Project Options, Journal of Enterprise Information Management, n. 20, 4, pp. 465-486.

http://dx.doi.org/10.1108/17410390710772722

European Commission (2009) Design as a Driver of User-Centred Innovation, Enterprise and Industry, Brussels, pp. 1-12.

Feitzinger Edward, Lee Hau L. (1997) Mass Customization at Hewlett-Packard: The Power of Postponement, Harvard Business Review, January/February, n. 1, pp. 116-121.

Halpin James F. (1966) Zero Defects: A New Dimension in Quality Assurance, McGraw-Hill, New York:.

Hayes Robert H. (1981) Why Japanese Factories Work, Harvard Business Review, July-August pp. 57- 66.

Hiam Alexander (1992) Closing the Quality Gap: Lessons from America's Leading Companies, Prentice Hall, Englewood Cliffs.

Hunt V. Daniel (1992) Quality in America: How to Implement a Competitive Quality Program. Business One Irwin, Homewood.

Imai Masaaki (1986) Kaizen: The Key To Japan's Competitive Success, McGraw-Hill Publishing Co., New York.

Jablonski Joseph R (1992) Implementing TQM, 2nd ed., Technical Management Consortium, Albuquerque.

Juran Joseph M.( ed.) (1995) A History of Managing for Quality: The Evolution, Trends, and Future Directions of Managing for Quality, The American Society for Quality Control, Milwaukee, Wisconsin:

Juran Joseph M. (1979) Quality Control Handbook, Third Edition, McGraw-Hill, NewYork.

Koostra Gert L. (2009) The Incorporation of Design Management in Today's Business Practices. An Analysis of Design Management Practices in Europe, Centre for Brand Reputation and Design Management, Rotterdam.

Kotler Philip, Rackham Neil, Krishnaswamy Suj (2006) Ending the War between Sales \& Marketing, Harvard Business Review, July/August, n. 84, 7/8, pp. 68-78.

Lambin Jean-Jacques (2000) Market-Driven Management: Strategic and Operational Marketing, MacMillan, London.

Levitt,Theodore (1983) The Globalization of Markets, Harvard Business Review, n. 61, 3, May/June, pp. 92-102.

Liedtka Jeanne, Ogilvie Tim (2011) Designing for Growth: A Design Thinking Tool Kit for Managers, Columbia University Press, New York.

Lua Yali Angela,Yu Guang Xiao, Sow Wai Zee, Jang Wei Loo (2012) Life Cycle Approach to Obsolescence Management, DSTA Horizons, pp.19-26.

Martin James R., Schelb W. K., Snyder R. C., Sparling J. C. (1992) Comparing the Practices of U.S. and Japanese Companies: The implications for Management Accounting, Journal of Cost Management, Spring, pp. 6-14.

Ordoñez Isabel, Rahe Ulrike (2013) Collaboration between Design and Waste Management: Can it Help Close the Material Loop?, Resources, Conservation and Recycling, March, n.72, pp. 108117.

http://dx.doi.org/10.1016/j.resconrec.2013.01.002

Reichwald Ralf, Bullinger Angelika C.(2008) Innovation and Ontologies: Structuring the Early Stages of Innovation Management, Springer, Munchen. 
Rieple Alison, Pironti Marco, PisanoPaola (2012) Business Network Dynamics and Diffusion of Innovation, Symphonya. Emerging Issues in Management (symphonya.unimib.it), n. 2, pp. 13-25. http://dx.doi.org/10.4468/2012.2.02rieple.pironti.pisano

Rieple Alison, Haberberg Adrian, Gander Jonathan (2005) Hybrid Organizations as a Strategy for Supporting New Product Development, Design Management Review, 16, pp. 48-55. http://dx.doi.org/10.1111/j.1948-7169.2005.tb00007.x

Rust Roland T., Moorman Christine, Bhalla Gaurav (2010) Rethinking Marketing, Harvard Business Review, January/February, pp.1-10.

Sasaoka Kenzo (1984) Our TQC Experience as a Partner of America, Seminar and Plant Tour to Study Productivity of Japanese Industry, The Cambridge Corporation, Tokyo.

Schmalensee Richard (1979) Market Structure, Durability and Quality: A Selective Survey, Economic Inquiry, n. 17, 2, April, pp. 177-196.

http://dx.doi.org/10.1111/j.1465-7295.1979.tb00307.x

Schmalensee Richard (1970) Regulation and the Durability of Goods, Bell Journal of Economic Goods and Management Science, n. 1, Spring, pp.54-64.

http://dx.doi.org/10.2307/3003022

Schneiderman Arthur M. (1986) Optimum Quality Costs and Zero Defects: Are TheyContradictory Concepts?, Quality Progress, n. 19, 11, November , pp.28-31.

Sung Tung-Jung, Lu Yi-Ta, Ho Shu-Shiuan (2010) Time-Based Strategy and Business Performance under Environmental Uncertainty: An Empirical Study of Design Firms in Taiwan, International Journal of Design, December, n. 4, 3, pp. 29-42.

Swan Peter L. (1972) Optimum Durability, Second-Hand Markets and Planned Obsolescence, Journal of Political Economy, n. 80, 3, May-June, pp.575-585.

http://dx.doi.org/10.1086/259906

Takeuchi Hirotaka (1981) Productivity: Learning from the Japanese, California Management Review, Summer, n. 23, 4, pp. 5-18.

http://dx.doi.org/10.2307/41164926

Turpin Dominique V. (1985) Japanese Approaches to Customer Satisfaction: Some Best Practices, Long Range Planning , June, n.3, pp.84-90.

http://dx.doi.org/10.1016/0024-6301(95)00014-A

von Hippel Eric (2005) The Democratization of Innovation, MIT Press, Cambridge.

von Stamm Bettina (2004) Innovation. What's Design Got to Do with It?, Design Management Review, n. 15, 1, Winter,pp. 10-19.

http://dx.doi.org/10.1111/j.1948-7169.2004.tb00145.x 